InCentives in Merchant EMpires: Portuguese ANd Dutch CoMpensation SCHEMES

by

Claudia Rei

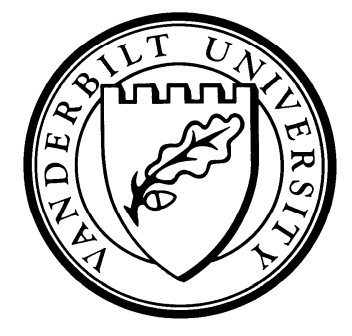

Working Paper No. 11-W12R

First Version: August 2011

Revised: October 2011

DEPARTMENT OF ECONOMICS

VANDERBILT UNIVERSITY

NASHVILLE, TN 37235

www.vanderbilt.edu/econ 


\title{
Incentives in Merchant Empires: Portuguese and Dutch Compensation Schemes
}

\author{
Claudia Rei* \\ Vanderbilt University
}

October 26, 2011

\begin{abstract}
The Portuguese and Dutch merchant empires had a similar geographic distribution with outposts all around the Indian Ocean, which they controlled and manned. Both empires faced the same problem of monitoring their agents in remote corners of the world. Each, however, arrived at a different solution to the monitoring problem. I use a principal-agent model to link different monitoring options to the different organizational structures of the two empires. I further investigate the implications of the model with archival data on labor compensation for Portuguese and Dutch workers overseas.
\end{abstract}

KEYWORDS: Merchant Empires, Labor Compensation, Monitoring

\footnotetext{
* I am grateful to Bob Margo and Andy Newman, for motivation and guidance, to Jeremy Atack, Andrea Moro, and Bill Collins for detailed suggestions on earlier drafts, and to Jeremy Atack for kindly generating Figure 2 in GIS. I also thank Andy Daughety, Yanqin Fan, Tong Li, Stephan Litschig, Debin Ma, Claudia Olivetti, Daniele Paserman, Jaime Reis, Thijs van Rens, Joachim Voth, two anonymous referees, the participants at the Clio meeting in Gettysburg, the World Economic History Congress in Utrecht, and the Labor workshop at Universitat Pompeu Fabra for helpful comments.
} 


\section{Introduction}

Recruiting the "right" people to risky ventures that cannot easily be supervised has always been a challenge. The problem was ever more present in sixteenth century Europe with the establishment of overseas trade empires, which attracted individuals with non-seasonal salaries but mostly with potential opportunities to make fortune.

In this paper I explore the incentive structures across merchant empires controlled by different parties. In Portugal merchants worked for the king and were therefore less invested in the outcome of the venture, monitoring workers less. In the merchant-controlled Dutch East India Company (Verenigde Oost-Indische Compagnie, henceforth VOC) on the contrary, workers were more closely monitored. These differences have stark theoretical implications from Principal-Agent theory, which is appropriate in the context of merchant empires since the owners of the enterprise (principals) and the workers (agents) are far removed from each other. Because worker's effort is difficult to observe, the principal can induce it by linking performance and pay according to the monitoring strategy in place: closely monitored workers have easily observable performance and receive a flat wage (low powered incentives); for workers subject to less monitoring, effort is harder to assess so they receive other forms of compensation beyond wage (high powered incentives).

The paper is an extension of previous work on the origins of the different control structures in merchant empires (Rei 2011). The diverse monitoring strategies result from the prior choice of organizational form and are therefore exogenous in the context of this paper. The current model highlights the differences in the structure of labor compensation of overseas workers conditional on the king/merchant control structure, but it does not explain the choice of monitoring levels. Four hundred years after the fact, it is difficult to identify the monitoring intensities of merchant empires. Surviving documents often provide a picture of what happened instead of a description of how it happened. To shed some light on the matter, I constructed a novel dataset on the labor compensation of Portuguese and Dutch overseas workers from the sixteenth to the eighteenth centuries. On average, Portugal paid a smaller 
portion of compensation in the form of wages than the VOC, allowing therefore for greater opportunities to exploit one's position and fortune making. ${ }^{1}$ This evidence is consistent with the monitoring hypothesis described above. I further investigate if the different wage policies were associated with observable worker characteristics that might have affected monitoring abilities, such as location, occupation and/or rank. Although monitoring is likely to have differed among workers of different rank, working for the king of Portugal still meant receiving lower wage shares. ${ }^{2}$

There is an extensive theoretical literature on incentives to generate effort. ${ }^{3}$ The use of bonuses in non-linear compensation schemes has been analyzed in the context of performance standards (Murphy 2000). Wages, have been the subject of study in as different contexts as deferred compensation or efficiency wages (Salop and Salop 1976 and Shapiro and Stiglitz 1984). The empirical evidence, on the other hand, is quite thin. Krueger (1991) finds differences in compensation schemes between company-owned and franchise-owned firms, which suggest that monitoring affects the compensation structure. Hejeebu (2005) addresses the complementarity of private trade and labor compensation to deal with the moral hazard problem in the British East India Company, suggesting yet alternative ways to deal with monitoring difficulties. Finally, Carlos (1992) examines the contract structure of the Hudson's Bay Company and the Royal African Company in order to deal with the problems of moral hazard and adverse selection associated with long-distance trade.

In this paper I look not at wages per se but rather at their relative size when considering other non-linear forms of compensation. I provide an explanation for the different pay schemes of Portuguese and Dutch overseas workers, illuminating the historical evidence on the incentives in merchant empires.

\footnotetext{
${ }^{1}$ This summary result was presented previously to show that organizational control had significant impact on the way merchant empires were run (Rei 2011).

${ }^{2}$ To incentivize effort empires could also have paid efficiency wages. However, overseas jobs were subject to a set of arduous conditions unlike those of the jobs offered in Europe, strenuous as they might have been. Upon data availability, we may compare wages of workers with different attitudes towards risk or skill. But, even if the empirical evidence showed higher wages in merchant empires this would not necessarily be a sign of an efficiency wage policy; it could just reflect the risk and skill premium of overseas jobs.

${ }^{3}$ For an overview of the general literature see Lazear 1995, Gibbons 1996, and Prendergast 1999.
} 


\section{Historical Background}

The sixteenth and seventeenth centuries saw the establishment of direct trade connections between Europe and East Asia with the emergence of merchant empires. All empires used the Cape Route to get to and from Asia. All established diplomatic agreements for exclusive trade with local rulers in order to guarantee a steady stream of spices to returning ships. The manipulation of quantity allowed Europeans to set prices, since spice surpluses above a targeted level were to be destroyed (Morris 1904, Hamilton 1948, Ames 2008). At sea all empires faced pirates and storms. On shore the challenge of establishing a functioning network of spice sources often led to military confrontation with other empires and local sovereigns when diplomatic efforts failed. Despite the many similarities, European nations organized their overseas ventures very differently.

Beginning in 1498, Portugal's merchant empire in the East was established with the king as the ultimate residual claimant of profits. This empire was headquartered in Goa (India) where a viceroy centralized all the governance from Mozambique to Macau, in the name of the king of Portugal (Diffie and Winius 1977). With a well-established network of ports, the Portuguese objective was to control all spice trade in Asia by taxing all ships sailing in the Indian Ocean (Pearson 1987, Subrahmanyam 1993). Such policy would thus directly interfere in the gains of the Levant trade and allow Portugal to become the unique middleman between Europe and Asia in an extremely profitable business.

The Dutch empire started with the foundation of the VOC in 1602, which effectively chartered Asian trade in the Netherlands to a group of private merchants. The residual claimants of the enterprise were the Heeren XVII, a board of seventeen delegates located in Amsterdam and selected from the managing shareholders of the original six chambers. The Dutch government itself had no direct involvement in Eastern trade other than the gain on customs duties and the payments at every renewal of the company's charter. In

the East, the VOC was centralized in Batavia (now Jakarta, Indonesia), the seat of the governor-general who responded directly to the Heeren XVII (De Vries and van der Woude 
1997). The governor-general effectively administered the company's activities from the Cape of Good Hope to Taiwan, with help from the Council of the Indies (Raad van Indië), created for government advice but also for preventing possible despotic temptations.

Despite the different organizational designs, both Portugal and the Netherlands operated in a period of slow inter-continental communication dictated by the distance and the monsoons. The first successful European voyage to the East lasted a little over two years: Da Gama sailed off of Lisbon on July 8, 1497 and returned on July 10, 1499 (Sanceau 1967:2178). Two-hundred years later at the height of the Dutch trade, the length of the round-trip was practically the same. The VOC's ships would depart the Netherlands in the spring of each year, arrived in Batavia nine months later and sailed back between November and March, arriving Amsterdam by the end of the following year (De Vries and van der Woude 1997:389). ${ }^{4}$ The time lag of the commercial cycle meant that the high degree of autonomy of both the Portuguese viceroy and the Dutch governor-general was unavoidable, which made efficient monitoring a matter of the utmost importance.

Both empires encountered similar challenges regarding the recruiting of personnel. Workers endured perilous voyages to Asia, facing a non-negligible probability of dying either from shipwreck or disease, only to meet more uncertainty and risk upon arrival. ${ }^{5}$ The Eastern destinations were often stricken by military conflict and ravaged by disease. Consequently, the compensation package had to provide a premium for overseas location, skill, and risk, as well as incentives for effort. These workers would effectively run the distant empire on the spot, while the owner of the enterprise remained safely in Europe.

The recruitment of workers in the merchant-controlled VOC followed a standard business approach. Family connections might have been relevant but prior information on prospective workers was unclear. Close monitoring would evaluate worker's effort after hiring, which eliminated the need for term contracts. In Portugal, most workers were selected from a

\footnotetext{
${ }^{4}$ Technological innovations in the sailing ship, the workhorse of long-distance trade, were largely irrelevant (North 1968).

${ }^{5}$ In Vasco Da Gama's 1498 voyage roughly two-thirds of the crew succumbed to scurvy (Sanceau 1967).
} 
pool of royal servants of the traditional nobility. ${ }^{6}$ Candidates could also come from the royal court, which included prominent bourgeois as well as local wealthy merchants who had rendered notable service to the king, such as helping in the discoveries. ${ }^{7}$ Even though the king of Portugal chose potentially loyal workers, he was not oblivious to possible moral hazard problems likely to occur in distant territories and when dealing with valuable products. Thus, labor contracts were limited to three years "lest by a longer term, [workers] might become too powerful and consequently insubordinate to the crown" (Morris 1904:222).

Loyalty to the crown was not necessarily the most desirable worker quality from a business point of view, but to the king it was. ${ }^{8}$ Portugal's personnel policy differed from that of the Netherlands' in terms of monitoring, not because the king was naïve, but because his objectives did not square with best business practices making all investments, including monitoring, costlier. Like merchants, monarchs cared for profit but unlike them they also cared for glory and recognition (Rei 2011). This latter component ultimately led to different business decisions across merchant empires, suggesting very different ventures despite their apparent similarities.

In this light, both monitoring schemes were optimal responses to each controlling party's incentives, exogenous in the current setting. The next section offers a principal-agent model linking monitoring to the type of compensation package offered to overseas workers.

\footnotetext{
${ }^{6}$ In a system where indivisible estates were inherited by the eldest son, the surplus of younger un-landed male siblings inclined to military training had little mercantile interest and engaged in trade through the use of skilled intermediaries (Subrahmanyam 1993:52).

${ }^{7}$ For example Fernão Gomes, a Lisbon merchant who conducted the private operation of Portuguese trade and discovery between 1469 and 1474, while paying rent to the crown. The discovery of gold in 1471 granted Gomes' knighthood. In 1474, the king reassumed control and formally admitted Gomes into the nobility with a new coat of arms. Later, Gomes became a member of the royal council (Barros 1988:67). Full admission into the nobility however, was not an alternative incentive for worker's effort since most workers already belonged to the traditional nobility. Moreover, Gomes' case was quite exceptional, not only for the quality of his services, but also because he was not a royal worker at the time. Such extraordinary and uncommon reward can be regarded as hiring a potential competitor. Regular rewards consisted of job posts in the East with the corresponding opportunities to make fortune.

${ }^{8}$ The recipient of the job might even not have been the originally targeted individual: often, the daughter of a deserving nobleman received from the king an office for her dowry (Pearson 1987:64).
} 


\section{A Model of Labor Compensation}

The Principal, located in Europe, manages a company owned by the king or the merchants. Among other tasks, the principal is in charge of designing labor contracts that induce workers' effort, and is risk-neutral in income. The Agent is hired in Europe to work in Asia, is riskaverse in income, and has preferences $u(w)-a$ with $u^{\prime}>0, u^{\prime \prime}<0 .^{9}$

The agent can exert effort or not, $a=\{1,0\}$. Either action is unobservable by the principal, who delegates monitoring in exchange for a signal indicating whether the agent is diligent $\left(\sigma_{1}\right)$ or not $\left(\sigma_{0}\right) .{ }^{10}$ Better monitoring costs more. The principal prefers an agent who works $(a=1)$, whereas the agent prefers to shirk $(a=0)$. The distribution of signal values depends on the agent's effort choice: if $a=1(a=0), \sigma_{1}\left(\sigma_{0}\right)$ arrives with probability $p(q<p)$ and $\sigma_{0}\left(\sigma_{1}\right)$ with probability $1-p(1-q)$. The precision of the signal - monitoring cost - is given by $\Delta=p-q$. Larger $\Delta$ implies a more informative, but also costlier, signal. The principal ties the agent's payoff to the observed signal: $w_{1}$ if $\sigma_{1}$, and $w_{0}$ otherwise.

Conditional on the information structure $\Delta$, the principal minimizes the expected labor compensation cost subject to the agent's incentive and participation constraints:

$$
\begin{aligned}
& \operatorname{Min}_{w_{1}, w_{0}} E[w \mid a=1, \Delta] \\
& \text { s.t. } p u\left(w_{1}\right)+(1-p) u\left(w_{0}\right)-1 \geq q u\left(w_{1}\right)+(1-q) u\left(w_{0}\right) \\
& \quad p u\left(w_{1}\right)+(1-p) u\left(w_{0}\right)-1 \geq \underline{u}
\end{aligned}
$$

The (binding) incentive constraint can be rewritten as

$$
u\left(w_{1}\right)=\frac{1}{\Delta}+u\left(w_{0}\right)
$$

\footnotetext{
${ }^{9}$ It is difficult to imagine risk-averse people selecting into employment in the other side of the world. Circa 1600, however, outside options were not great. An overseas job could be the opportunity to make a fortune and gain social status.

${ }^{10}$ In the standard principal-agent model profit is a possible measure of performance to which the principal may tie the agent's payoff. In this paper I separate profitability from the information structure, hence the signal notation. The results do not depend on this specification.
} 
the less informative the signal, the larger the payoff dispersion. In the two-state model the contract is determined entirely by the two constraints, both of which bind. The result is:

$$
u\left(w_{0}\right)=\underline{u}+1-\frac{p}{\Delta} \text { and } u\left(w_{1}\right)=\underline{u}+1+\frac{1-p}{\Delta} .
$$

Poor monitoring (low $\Delta$ ) increases the gap between payoffs associated with good $\left(w_{1}\right)$ and bad signals $\left(w_{0}\right)$. If we interpret $w_{0}$ as the wage, and $w_{1}-w_{0}$ as the compensation beyond wage, then the wage share of total compensation becomes

$$
\frac{w_{0}}{w_{1}}=\frac{v\left(\underline{u}+1-\frac{p}{\Delta}\right)}{v\left(\underline{u}+1+\frac{1-p}{\Delta}\right)}, \text { where } v(.)=u^{-1}(.) \text {. }
$$

Since $v($.$) is increasing, the wage share rises in \Delta$. The predictions of the model are straightforward: better information leads to more reliance on wages or low powered incentives, which imply lower expected compensation. Thus, while high values of $\Delta$ minimize compensation costs, they are also more onerous since securing better information on workers is more expensive. In the less efficient organization, the principal earns a lower return from every investment, including monitoring, and therefore makes less use of it. The optimal labor contract will therefore offer a lower wage share of total compensation, an implication that can be assessed in the data.

\section{Data}

The Portuguese data were extracted from a manuscript from ca. 1582 addressed to the king of Spain shortly after Portugal's transfer of independence in 1580 (Luz 1960). The document - whose anonymous author was probably a former high secretary of state - seems to fill the purpose of providing information about the conditions of the newly acquired eastern empire. As a consequence, the data are a summary of almost one hundred years of Portuguese operations rather than representative of 1582 alone. With the exception of the island of 
Ternate (now Indonesia), the Portuguese strongholds in the East remained intact since the 1520 s - the last decade of conquests in Asia.

The document has seventeen chapters each corresponding to a specific outpost from Sofala (now Mozambique), to Ternate, and also Macao (China). ${ }^{11}$ A typical chapter starts with a detailed description of the location and is followed by the list of all its job positions with corresponding wage paid by the king of Portugal and the amount of above wage income allowed. ${ }^{12}$ The seventeen chapters provide the complete set of job positions of European officials (e.g. captains, factors, scribes) across all locations (e.g. Goa, Ormuz, Timor) of the Portuguese empire. There are 198 observations. ${ }^{13}$

Labor compensation has two components: a yearly fixed wage paid by the Royal Treasury and a supplemental income to which Portuguese officials were entitled for the term of the contract. This extra income could take the form of privileges attached to a certain post (e.g. imports of spices, intra-Asian trade); gifts and payments from local jurisdictions (often extorted); or financial advantages attached to the position such as lending money or providing supplies in the areas of jurisdiction. The size of this income beyond wage depended on local conditions (e.g. war, agricultural year) but also on the official's ability to make use of the position. Some locations (e.g. Ternate) are mentioned to have yielded higher amounts in the past, but such was no longer the case due to war, or because current workers were not diligent enough. In sum, non-wage income was dependent on the empire's maintenance and performance, both of which relied on worker's effort.

The Dutch data were collected from a detailed historical study of the VOC's personnel (Lequin 1982). In particular, the study provides complete records for 115 workers who spent

\footnotetext{
${ }^{11}$ See Figure 2 for a detailed map of the Portuguese and Dutch trading centers in the data.

${ }^{12}$ In the preface, Luz notes that the description of job posts and their compensation is not merely statistical. There are often comments on the current values associated with a given location or occupation. The author also adds his own critical opinion on as diverse issues as territorial defense, or the nomination of personnel. Such statements help to understand the adverse circumstances the faced in the East, as well as the management and personnel practices of the empire.

${ }^{13}$ Workers in the Portuguese eastern empire were very likely more than 198 . However, locally hired labor (e.g. to load and unload ships) is not in the data, which also does not contain Portuguese workers selected for office under the patronage of high rank officials, such as city captains (Pearson 1987:64).
} 
at least some time in Bengal between 1669 and 1799, one year before the dissolution of the company. Among other characteristics, from the date of entry to that of exit, I observe worker's location, occupation, date of promotion, total wage payments (similar to the wage component in the Portuguese package), and total value accrued beyond wage (similar to the supplemental income in the Portuguese package). ${ }^{14}$ Like the Portuguese, all Dutch workers in the sample were hired in their home country. ${ }^{15}$

The two datasets differ in that the Portuguese covers job posts over three-year periods, whereas the Dutch presents individual careers lasting twenty-two years on average. The different contract duration however, is not necessarily dictating the observed incentive structure: longer terms may have allowed workers greater fortune-making possibilities, reducing the need for large incentives; on the other hand however, these workers were exposed to eastern dangers (war and disease) for longer periods, so they might have required more incentives to take such jobs. As such, both datasets provide total career compensation (even if careers have different lengths) divided in wage and above wage income and therefore allowing for cross-country comparisons.

Table 1 shows the wage shares of total compensation for Portuguese and Dutch workers. This is a convenient variable to analyze as it abstracts from the different currencies. The average Portuguese wage share is roughly two-thirds of the Dutch. The Portuguese shares are more dispersed - Figure 1 - which, according to the model, is a sign of a poorer information structure in place (low $\Delta$ ). Also the Portuguese distribution lies mostly to the left of the Dutch distribution, indicating a compensation structure less reliant on wages.

To account for the possibility that the Netherlands, the late entrant, may have learned from Portugal's mistakes and adjusted wage shares upward, I divided Dutch workers in two groups according to the date of entry (before and after 1724). If better monitoring

\footnotetext{
${ }^{14}$ It is possible that the VOC rewarded its workers with promotions instead of non-wage income, which is consistent with the model: a promotion strategy was likely to require more and closer monitoring of workers.

${ }^{15}$ Of the 115 observed workers, seven were born in Asia but their first and last names are European. I therefore assume that they were descendants of VOC workers and not locally hired labor for low skilled occupations, which makes these workers similar to those originally hired in the Netherlands.
} 
techniques became available, Dutch compensation would have shifted towards larger wage shares in a later stage. ${ }^{16}$ The last two columns of Table 1 reveal the opposite pattern. Dutch workers entering the VOC after 1724 have lower wage shares of compensation than workers entering before that year: the older the Dutch company, the closer the compensation structure becomes to the Portuguese. This phenomenon may be associated with the decline of the VOC, but it does not seem to endorse Dutch learning from Portuguese mistakes.

\section{$5 \quad$ Alternative Hypotheses and Results}

The data allow for the analysis of variables other than organizational control, which could potentially affect the compensation structure. Different monitoring strategies, and consequently wage shares, could plausibly result from differences in worker's location, occupation or rank according to the following hypotheses:

$H_{1}$ workers in spice-producing locations, such as Indonesia, may have been easier to monitor than workers in locations with less tangible outcomes such as the administrative cities of Goa and Bengal, or relatively less prolific spice locations in the Malabar Coast (Southwest India), or even strategic locations like the Cape of Good Hope. To account for these differences, I divided locations into Indonesia and Other Regions;

$H_{2}$ workers in the civil sector may have been easier to monitor than workers at sea or in the military as they were less mobile and arguably had fewer smuggling opportunities. I divided occupations into sectors of activity - Civil, Sea, and Military;

$H_{3}$ low-rank jobs may have encompassed simpler tasks, which would have been easier to monitor. Based on the firm's hierarchy provided in each document, every occupation above the middle was classified as High-rank and below as Low-rank. ${ }^{17}$

Table 2 presents descriptive statistics. Dutch variables report workers' location, sector, and rank for more than $50 \%$ of the career. ${ }^{18}$ The majority of the observations are located

\footnotetext{
${ }^{16}$ The result is identical if the date of exit (and not entry) is taken into account.

${ }^{17}$ The hierarchies of both empires are similar and available from the author upon request.

${ }^{18}$ Start and ending variables vary considerably: most Dutch workers arrived in Batavia but ended their
} 
in India, which is driven mainly by Portuguese workers. Both samples consist of workers mainly in the civil sector, and both have $64 \%$ of the workers in a low-rank job.

The following regression tests all variables possibly affecting compensation structure:

$$
\frac{w_{j}}{w_{j}+z_{j}}=\beta_{0}+\beta_{1} d\left(\text { Crown }_{j}\right)+\beta_{2} d\left(H_{i j}\right)+\beta_{3} d\left(\text { Crown }_{j}\right) \times d\left(H_{i j}\right)+\varepsilon_{j}, \text { with } i=1,2,3 \text {. }
$$

The left-hand side represents worker $j$ 's wage share of compensation $\left(w_{j}\right.$ being wage and $z_{j}$ the extra income). On the right hand side, beyond the error term $\varepsilon_{j}$, there are several dummy variables: $d\left(\right.$ Crown $\left._{j}\right)$, the organization dummy, equals 1 if worker $j$ 's firm is controlled by the king; $d\left(H_{i j}\right)$, the alternative hypotheses dummies, each equal to 1 if worker $j$ is located in Indonesia, belongs to the Civil sector, or has a Low-rank occupation. The cross products explore the difference in treatment of workers in different firms (with different monitoring), with respect to the difference regarding each of the alternative hypotheses $H_{i}$.

Given the patterns in Table 1 we would expect a negative correlation between the wage share and a firm controlled by the crown, $\beta_{1}<0$. The Location, Sector and Rank hypotheses lead us to expect $\beta_{2}>0$ for all $H_{i}$.

The first three columns in Table 3 test each of $H_{1}, H_{2}$ and $H_{3}$ separately against organization, while the fourth tests all hypotheses jointly. $\beta_{1}$ is always negative and significant: working for the Portuguese king meant, on average, a lower fraction of compensation in the form of wages. The Location hypothesis $\left(H_{1}\right)$ is not supported by the data: wage shares were not significantly different for workers in Indonesia, possibly indicating that monitoring offered similar challenges across all locations of the empire. The Sector and Rank hypotheses $\left(H_{2}\right.$ and $\left.H_{3}\right)$, on the other hand, cannot be rejected due to significant $\beta_{3}$ : Portuguese civil servants and low-rank workers seem to have received larger wage shares than Dutch workers not in the civil sector or in high-rank positions.

The fourth column in Table 3 includes all explanatory variables and cross products.

careers in Bengal; 64\% started in the civil sector and almost all (97\%) end there; career progress in the VOC was very clear - $90 \%$ of the workers started in low-rank positions but only $36 \%$ are last observed as such. These differences do not change the results. 
Again $\beta_{1}$ is negative and highly significant even after controlling for all possible alternatives affecting the wage share. The Sector hypothesis is no longer verified but the Low-rank coefficient remains significant, if summed with $\beta_{1}$ indicates that, on average, Portugal paid a wage share of compensation $32.9 \%$ lower than the Netherlands. ${ }^{19}$

The lower Dutch shares could be associated with the way in which the data were constructed. Worker's location, sector and rank are attributed to the place, industry or category where workers spent more than $50 \%$ of their careers. The problem exists if the initial $30 \%$ of Dutch careers were spent in low-wage locations/sectors/rank, while in the remaining $70 \%$ the reverse occurred. The classification criterion would only capture the latter part of the Dutch careers, "helping" the model. If the pattern was similar for Portuguese workers (of which I only capture one contract) then the model fully explains the artificial result.

The last two columns in Table 3 demystify this conjecture. First, the only significant explanatory variable in the Dutch regression is that of the civil sector but since it is negative, Dutch civil servants were associated with lower wage shares and not the opposite as $\mathrm{H}_{2}$ suggests. ${ }^{20}$ Second, for Portuguese workers the only significant variable is Low-rank, which is associated with higher wage shares; even though $64 \%$ of Portuguese workers belong to this category, their wage shares are still lower than the Dutch.

\section{Concluding Remarks}

I use a principal-agent model to illustrate differences in the compensation structures of Portuguese and Dutch overseas workers from the sixteenth to the eighteenth centuries. In the case of poor worker information, the model predicts lower wage fractions of total compensation so that there is a stronger incentive to work hard. This theoretical result matches the observed historical evidence: on average Portuguese royal servants were paid lower wage

\footnotetext{
${ }^{19}$ There are thirty-nine workers with zero wages, all of them Portuguese, which makes $\frac{w_{j}}{w_{j}+z_{j}}$ zero for a non-trivial number of observations (12\%). Tobit estimations yield similar results to the reported OLS.

${ }^{20}$ Given that only $3 \%$ of Dutch workers were not civil servants, the negative coefficient probably says more about the omitted workers.
} 
shares than Dutch VOC workers, which is consistent with a scenario in which Portuguese workers were monitored less since it was costlier.

Portuguese overseas positions were effectively rewards for prior services and acknowledged opportunities to make fortune from the large fractions of income beyond wages. Dutch workers also received a notable component of compensation in this form, but it was significantly smaller than the Portuguese counterpart, a result which holds even after controlling for alternative explanations that may have affected wage shares, such as worker's location, sector, and rank.

The historical evidence on labor compensation indicates distinct worker incentives according to the control structure, suggesting the Portuguese and Dutch merchant empires were very different enterprises even though they traded in similar products and regions. 


\section{References}

[1] Ames, G. J., 2008. The Globe Encompassed: The Age of European Discovery, 1500-1700. Pearson Prentice Hall.

[2] Barros, J., 1988. Ásia de João de Barros: Dos feitos que os Portugueses fizeram no descobrimento e conquista dos mares e terras do Oriente. Lisboa: Imprensa Nacional Casa da Moeda. (Orig. pub. 1552)

[3] Carlos, A., 1992. "Principal-Agent Problems in Early Trading Companies: A Tale of Two Firms." American Economic Review 82, no. 2, Papers and Proceedings of the Hundred and Fourth Annual Meeting of the American Economic Association, 140-145.

[4] De Vries, J. and A. M. van der Woude, 1997. The first modern economy: success, failure, and perseverance of the Dutch Economy 1500-1815. Cambridge; New York: Cambridge University Press.

[5] Diffie, B. W. and G. D. Winius, 1977c. Foundations of the Portuguese Empire, 14151850. Minneapolis: University of Minnesota Press.

[6] Gibbons, R., 1996. "Incentives and Careers in Organizations." NBER Working Paper 5705.

[7] Hejeebu, S., 2005. "Contract Enforcement in the English East India Company." Journal of Economic History 65, 496-523.

[8] Hamilton, E.J., 1948. "The Role of Monopoly in the Overseas Expansion and Colonial Trade of Europe Before 1800." American Economic Review 38, no. 2, Papers and Proceedings of the Sixtieth Annual Meeting of the American Economic Association, $33-53$.

[9] Krueger, A.B., 1991. "Ownership, Agency, and Wages: An Examination of Franchising in the Fast Food Industry." Quarterly Journal of Economics 106, no. 1, 75-101. 
[10] Lazear, E.P., 1995. Personnel Economics. Cambridge and London: MIT Press.

[11] Lequin, F., 1982. Het personeel van de Vereengide Oostindische Compagnie in Azie. Leiden: F. Lequin.

[12] Luz, F.P.M., 1960. Livro das Cidades e Fortalezas, que a Coroa de Portugal tem nas partes da India e das Capitanias, e mais cargos que nelas ha, e da importância delles. Lisboa: Centro de Estudos Históricos Ultramarinos.

[13] Morris, H.C., 1904. History of Colonization - from the Earliest Times to the Present Day. New York and London: The Macmillan Company.

[14] Murphy, K. J., 2000. "Performance Standards in Incentive Contracts." Journal of Accounting and Economics 30, no. 3, 245-278.

[15] North, Douglass. "Sources of Productivity Change in Ocean Shipping, 1600-1850," Journal of Political Economy 76, no. 5 (1968): 953-970.

[16] Pearson, M. N., 1987. The New Cambridge History of India: The Portuguese in India. Cambridge: Cambridge University Press.

[17] Prendergast, C., 1999. "The Provision of Incentives in Firms." Journal of Economic Literature 37, no. 1, 7-63.

[18] Rei, C., 2011. "The Organization of Eastern Merchant Empires," Explorations in Economic History 48, 1 (2011): 116-135.

[19] Salop, S. and J. Salop, 1976. "Self-Selection and Turnover in the Labor Market." Quarterly Journal of Economics 90, no. 4, 619-27.

[20] Sanceau, E., 1967. Good Hope - The Voyage of Vasco da Gama. Lisboa: Academia Internacional da Cultura Portuguesa. 
[21] Subrahmanyam, S., 1993. The Portuguese Empire in Asia 1500-1700: A Political and Economic History. London and New York: Longman.

[22] Shapiro, C. and J. Stiglitz, 1984. "Equilibrium Unemployment as a Discipline Device." American Economic Review 74, no. 3, 433-44. 
Figure 1: Distribution of Wage Shares of Compensation

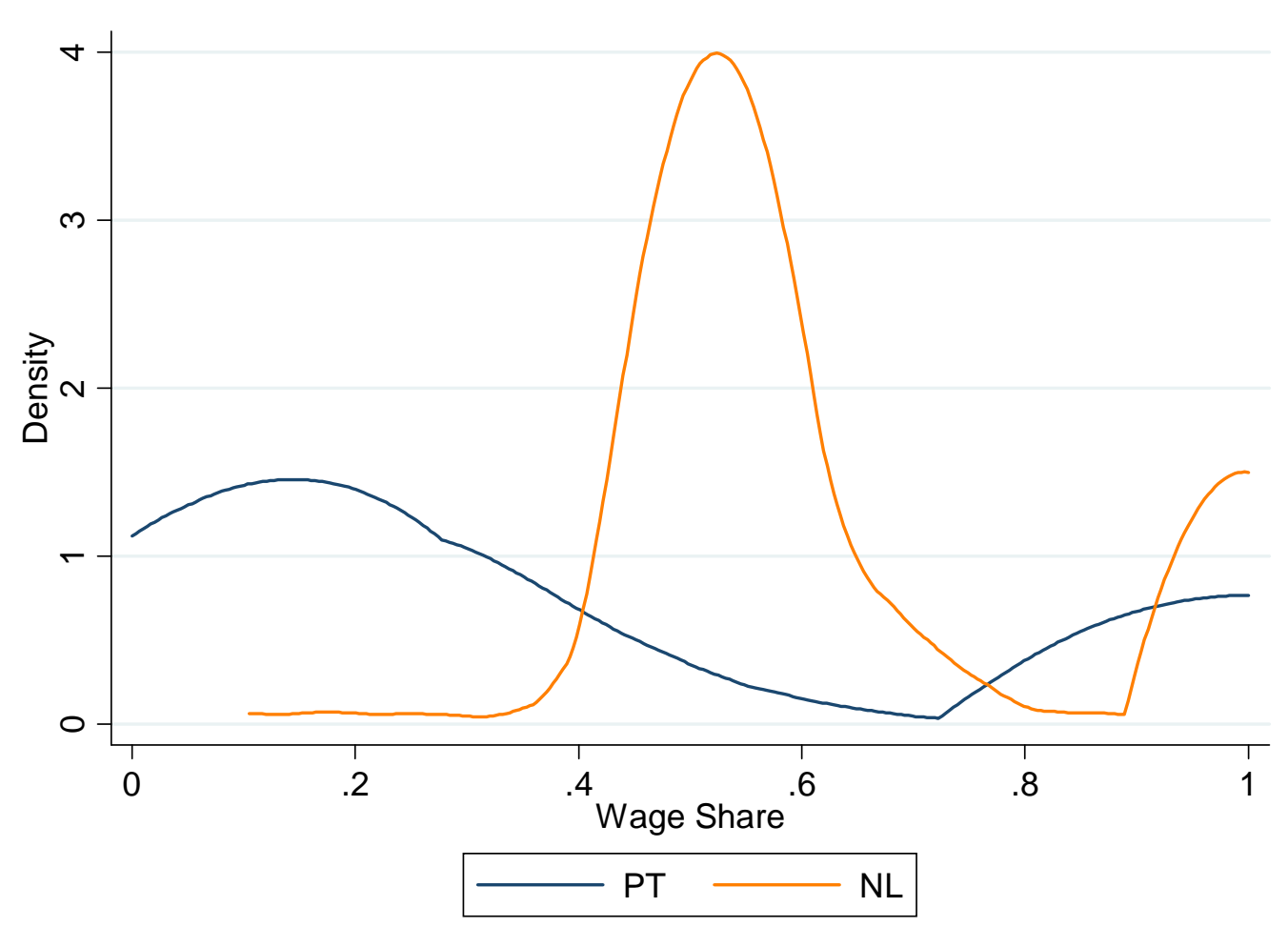




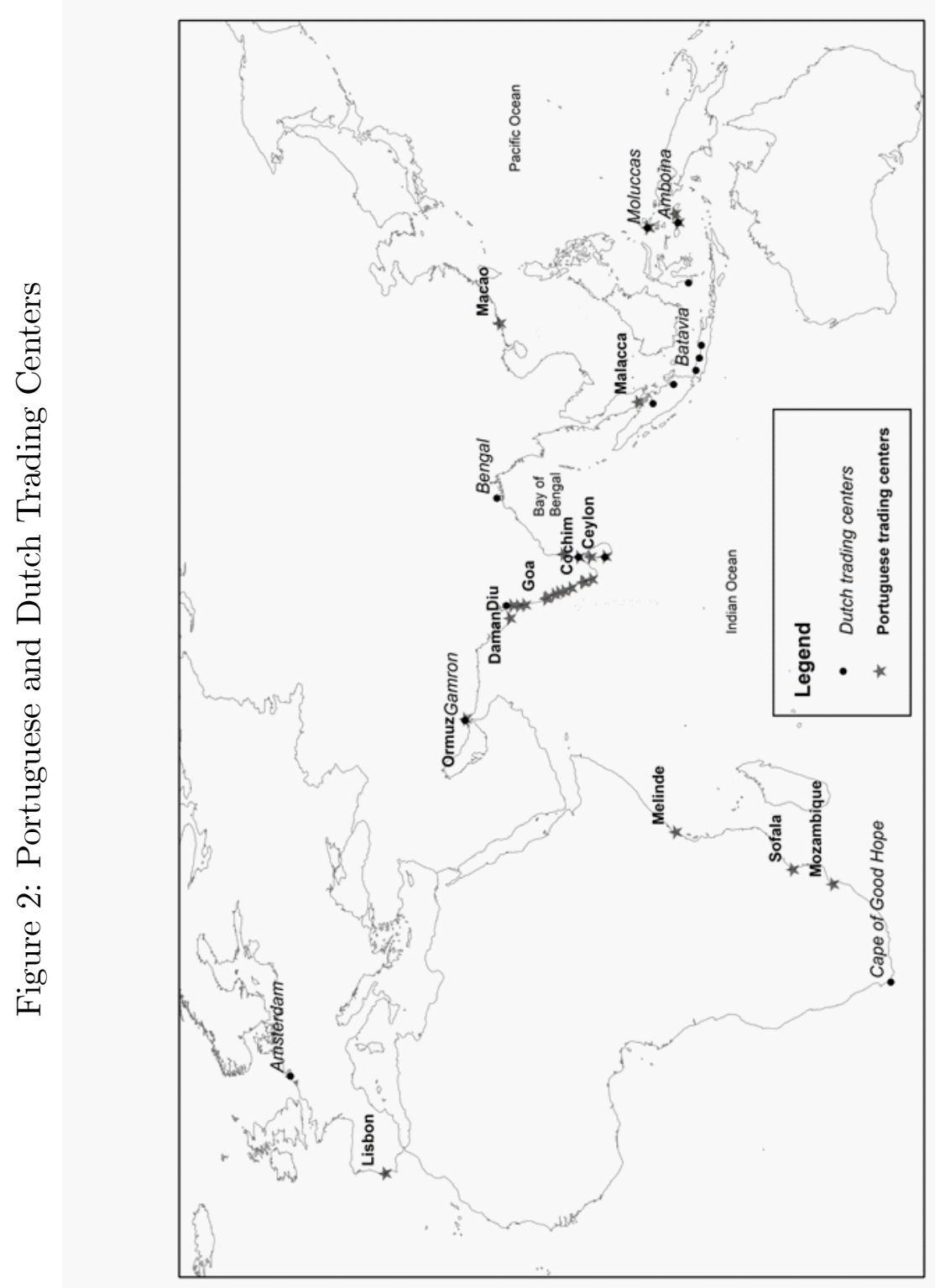


Table 1: Descriptive statistics: Wage Shares of Total Compensation

\begin{tabular}{l|cc|c|cc}
\hline \hline & Portugal & Netherlands & Total & NL early & NL late \\
\hline Average & .402 & .637 & .489 & .713 & .575 \\
Median & .235 & .534 & .345 & .601 & .529 \\
St. Dev. & .396 & .209 & .358 & .240 & .156 \\
Min. & .000 & .105 & .000 & .247 & .105 \\
Max. & 1.00 & 1.00 & 1.00 & 1.00 & 1.00 \\
\hline $\mathrm{N}$ & 198 & 115 & 313 & 52 & 63 \\
\hline
\end{tabular}

Sources: Lequin (1982), Luz (1960).

Table 2: Descriptive Statistics: Workers by Location, Occupation and Rank - percentages

\begin{tabular}{lccc}
\hline \hline & Portugal & Netherlands & Total \\
\hline India & 0.73 & 0.23 & 0.54 \\
Indonesia & 0.11 & 0.58 & 0.28 \\
Other & 0.16 & 0.19 & 0.18 \\
\hline Civil & 0.76 & 0.97 & 0.83 \\
Sea & 0.06 & 0.03 & 0.05 \\
Military & 0.18 & 0.00 & 0.12 \\
\hline Low-rank & 0.64 & 0.64 & 0.64 \\
High-rank & 0.36 & 0.36 & 0.36 \\
\hline $\mathrm{N}$ & 198 & 115 & 313 \\
\hline Sources: Lequin (1982), Luz (1960). & &
\end{tabular}

Table 3: Dependent Variable - Wage Share of Compensation (OLS)

\begin{tabular}{|c|c|c|c|c|c|c|}
\hline & $\left(\mathrm{H}_{1}\right)$ & $\left(\mathrm{H}_{2}\right)$ & $\left(\mathrm{H}_{3}\right)$ & $\begin{array}{l}\text { (All) } \\
\end{array}$ & $\overline{(\mathrm{NL})}$ & $\overline{(\mathrm{PT})}$ \\
\hline Crown & $-.258^{* * *}$ & $-.517^{* * *}$ & $-.404^{* * *}$ & $-.615^{* * *}$ & $\mathrm{NO}$ & YES \\
\hline Indonesia & -.031 & & & -.022 & -.022 & .063 \\
\hline Civil & & -.247 & & -.232 & $-.232^{* *}$ & -.060 \\
\hline Low-Rank & & & -.058 & -.054 & -.054 & $.232^{* * *}$ \\
\hline Crown*Indonesia & .081 & & & .085 & & \\
\hline Crown*Civil & & $.306^{*}$ & & .171 & & \\
\hline Crown*Low-Rank & & & $.265^{* * *}$ & $.186^{* * *}$ & & \\
\hline _Cons & $.655^{* * *}$ & $.876^{* * *}$ & $.675^{* * *}$ & $.908^{* * *}$ & $.908^{* * *}$ & $.293^{* * *}$ \\
\hline$\overline{\mathrm{N}}$ & 313 & 313 & 313 & 313 & 115 & 198 \\
\hline $\mathrm{R}^{2}$ & 0.1022 & 0.1094 & 0.1515 & 0.1618 & 0.0647 & 0.0689 \\
\hline
\end{tabular}

